been helped by some clear sketches that explain the mysteries of retrovirology.

Because the meeting on which this book is based was confined to the retroviral approach to gene transfer, Human Gene Therapy does not provide a comprehensive picture of the field. For example there is no discussion of the possibility of gene replacement by site-directed recombination or by the reactivation of the fetal globin genes to treat the more severe haemoglobin disorders. And some of the ethical issues are dealt with in rather a parochial way. But, with these minor reservations, the book is an excellent introduction for newcomers to this biomedical minefield.

Although somatic gene therapy is no different in principle to organ transplantation, it remains a highly emotive topic. Many clinicians are concerned that, in their haste to be first, workers in this field will cut corners, both scientific and ethical. Anyone who has such worries should read this book. Its clear and critical account of the complexities of the problem, both scientific and ethical, will do much to reassure them that researchers in the United States are putting their house in order. The recent guidelines on gene therapy research issued by the European Research Councils should be equally comforting.

It is particularly reassuring to read that work is being confined to somatic gene therapy. The alternative approach, germline therapy, in which genes are inserted into fertilized eggs and hence passed on to future generations, is a non-starter; it should remain so. Provided that, with adequate regulation, research on the very early human conceptus is allowed to continue it should be possible to learn how to identify a genetic disease in fertilized ova and to return to the mother only those which do not carry the harmful gene. But although prenatal diagnosis of genetic disease will reduce the number of affected births, many disorders will continue to go undetected. This is why somatic gene therapy will play an important role in clinical practice in the future. But judged by this book, this tour de force of medical science will remain just round the corner for a while yet.

Sir David Weatherall is Nuffield Professor of Clinical Medicine in the University of Oxford, John Radcliffe Hospital, Oxford OX $39 D U, U K$.

\section{Natural goodness}

\section{Vernon Reynolds}

The Waning of Humaneness. By Konrad Lorenz. Translated by Robert Warren Kickert. Unwin Hyman: 1988. Pp. 250. f12.95.

Published in German in 1983, only now has this profound book been translated for an English-speaking public. The Lorenz who speaks here is the same Lorenz from the days of On Aggression. I recall an ethology congress in the 1960 s when we, the delegates, wore flowers in our buttonholes for the great man's address, which was on "The Decline of Youth" or some such topic. The same theme occurs in this new book, 20 years on. Youth is not so much blamed as offered condolences for its boredom and deep distrust of the older generation.

The old thinking, which Lorenz now calls "evolutionary epistemology", has been extended and deepened. It is now more coherent and philosophically rooted than it was then. We human beings are viewed as products of nature, the potentials and limitations of the human mind arising from our animal background. Its potentials include joy and wonder and creativity; its limitations are a poverty of comprehension in large-scale society and a willingness to follow demagogues and those offering false hopes. These limitations are dubbed "malfunctions of once meaningful behaviour patterns".

\section{IMAGE UNAVAILABLE FOR COPYRIGHT REASONS}

\section{Konrad Lorenz - opposing urbanization.}

The evolutionary theory of knowledge that Lorenz here espouses is a humanbased theory in a very literal sense. It is not founded on mathematical logic nor on reason nor on any theory of teleonomy or of inevitability. It begins and ends with a particular evolved species - the human being - and with the psycho-physiological properties of that species. In a remarkable insight, Lorenz discovers that, from this premise, human emotional feelings and sense-data are "valid", as indeed are the emotions and perceptions of each and every species. They are indeed more valid than the truths declared by mere verbal rationality, and far more so than the very suspect values of modern technocratic society. Empirical science may lay claim to valid truths, but the truths we perceive and feel are valid too.

From this insight Lorenz assembles his naturalistic philosophy. Man is basically good; civilization distorts the evolved feelings and perceptions that arise in each of us. The a priori values, the natural goods and evils, have become perverted by our Western culture, and modern man is now totally confused about what is good and what is evil. In our huge societies, a small power élite controls the mass of the population; things have gone psychologically wrong on both sides of the divide. Big business in particular is blamed for man's loss of humaneness; small enterprises can be humane but they are powerless against the giants.

Worst of all are the urbanized. They "come in contact almost exclusively with only non-living and, above all, with manmade things, and they have learned to come to terms with almost all of them". However, "they treat everything living . . with sheer, unbelieveable shortsightedness...they regard everything as makable .... These epistemologically mistaken paths of human thought and reasoning have irremediable consequences" (pp. 166-167).

Enough. What is to be made of Lorenz's philosophy? Two criticisms of it seem in order. First, it claims universal validity. What is small is good, what is orderly is good, what is natural for man to think, perceive and do is good. But Lorenz himself is the arbiter of the natural, and that surely won't do. He would claim that nature, ethology, other species are the arbiters. But this is not so; there has been a new wave of sociobiological concepts, postdating Lorenz, and these generate quite different ideas of the natural. What is natural is not self-evident even in the animal world, let alone the human.

Secondly, despite his evident efforts to place his ideas in the context of the work of others, Lorenz has concentrated too narrowly on the ideas of a few German philosophers (Kant, Gehlen, Planck and Spengler receive mention). His positive evaluation of the natural over the urban and man-made certainly goes back to Virgil's Georgics, and although his is a scientific philosophy, based on the theory of evolution and the findings of empirical research, his ultimate assumption about the validity of emotional and sense data is only scientific in the widest sense indeed he attacks conventional reductionist science for its inadequacy and bigotry. This must place him in the camp of the natural philosophers generally, for they mostly eschew science in the narrow sense. Wordsworth's pantheism is not far from Lorenz's evolutionary epistemology when the chips are down.

Vernon Reynolds is a Lecturer in the Department of Biological Anthropology, University of Oxford, 58 Banbury Road, Oxford OX2 6QS, UK. 